Original Article

\title{
Antioxidant potential and $\alpha$-glucosidase inhibitory activity of onion (Allium cepa L.) peel and bulb extracts
}

\author{
Atividade antioxidante e potencial inibidor de $\alpha$-glucosidase de extratos de casca e \\ bulbo de cebola (Allium cepa) preparados por etanol e água
}

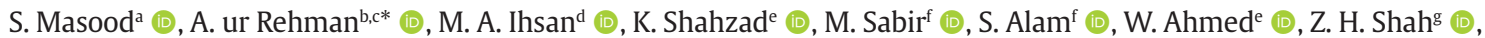 \\ F. Alghabarih (D, A. Mehmoodi (D) and G. Chung;* (D) \\ aUniversity of Lahore, Faculty of Allied Health Sciences, University Institute of Diet and Nutritional Sciences - UIDNS, Lahore, Pakistan \\ ${ }^{b}$ Natural Resources Institute (Luke), Horticulture Technologies, Production Systems Unit, Piikkiö, Finland \\ 'University of Helsinki, Faculty of Agriculture and Forestry, Department of Agricultural Sciences, Helsinki, Finland \\ dUniversity of Padova, Department of Agronomy, Animals, Food, Natural Resources and Environment - DAFNAE, Padova, Italy \\ 'The University of Haripur, Department of Plant Breeding and Genetics, Haripur, Pakistan \\ 'The University of Haripur, Department of Microbiology, Haripur, Pakistan \\ gPir Mehr Ali Shah Arid Agriculture University, Department of Plant Breeding and Genetics, Rawalpindi, Pakistan \\ hKing Abdulaziz University, Department of Arid Land Agriculture, Jeddah, Saudi Arabia \\ iThe University of Haripur, Department of Soil \& Climate Sciences, Haripur, Pakistan \\ jChonnam National University, Department of Biotechnology, Yeosu, Chonnam, South Korea
}

\begin{abstract}
Allium cepa L. is a commonly consumed vegetable that belongs to the Amaryllidaceae family and contains nutrients and antioxidants in ample amounts. In spite of the valuable food applications of onion bulb, its peel and outer fleshy layers are generally regarded as waste and exploration of their nutritional and therapeutic potential is still in progress with a very slow progression rate. The present study was designed with the purpose of doing a comparative analysis of the antioxidant potential of two parts of Allium cepa, i.g., bulb (edible part) and outer fleshy layers and dry peels (inedible part). Moreover, the inhibitory effect of the onion bulb and peel extracts on rat intestinal $\alpha$-glucosidase and pancreatic $\alpha$-amylase of porcine was also evaluated. The antioxidant potential of onion peel and bulb extracts were evaluated using 2,2-diphenyl- 1-picryl hydrazyl (DPPH), ferric-reducing antioxidant power assay (FRAP), 2,2'-azino-bis- 3-ethylbenzothiazoline-6-sulfonic acid (ABTS) radical scavenging assay, $\mathrm{H}_{2} \mathrm{O}_{2}$ radical scavenging activity and $\mathrm{Fe}^{2+}$ chelating activity. Total flavonoids and phenolic content of ethanolic extract of onion peel were significantly greater as compared to that of onion bulb. Ethanolic extract of onion peel also presented better antioxidant and free-radical scavenging activity as compared to the ethanolic extract of bulb, while the aqueous extract of bulb presented weakest antioxidative potential. Onion peel extract's $\alpha$-glucosidase inhibition potential was also correlated with their phenolic and flavonoid contents. The current findings presented onion peel as a possible source of antioxidative agents and phenolic compounds that might be beneficial against development of various common chronic diseases that might have an association with oxidative stress. Besides, outer dry layers and fleshy peels of onion exhibited higher phenolic content and antioxidant activities, compared to the inner bulb. The information obtained by the present study can be useful in promoting the use of vegetable parts other than the edible mesocarp for several future food applications, rather than these being wasted.
\end{abstract}

Keywords: bioactive compounds, bio-waste, flavonoids, oxidative stress, phenolic content.

\begin{abstract}
Resumo
Allium cepa pertence à família Liliaceae e é rica em nutrientes e antioxidantes. Apesar das expressivas aplicações alimentares do bulbo da cebola, sua casca e outras camadas externas são geralmente consideradas resíduos, e seu potencial nutricional e terapêutico ainda é pouco explorado. 0 presente estudo foi delineado com o objetivo de investigar comparativamente o potencial antioxidante de duas partes de Allium cepa, por exemplo o bulbo (parte comestível) e camadas externas e cascas secas (parte não comestível). Além disso, o efeito inibitório dos extratos do bulbo de cebola e casca sobre a $\alpha$-glucosidase intestinal de ratos e $\alpha$-amilase pancreática suína também foi avaliado. $O$ potencial antioxidante dos extratos da casca de cebola e bulbo foi avaliado utilizando-se 2,2-difenil1-picrilhidrazil (DPPH), método de poder antioxidante de redução do ferro (FRAP), método 2,2'-azino-bis-3etilbenzotiazolina-6-ácido sulfônico (ABTS) de eliminação de radicais, atividade de eliminação de radicais $\mathrm{H}_{2} \mathrm{O}_{2}$ e atividade quelante do $\mathrm{Fe}^{2+}$. Os flavonoides totais e os teores fenólicos do extrato de etanol da casca de cebola
\end{abstract}

*e-mail: attiq.rehman@luke.fi; chung@chonnam.ac.kr

Received: January 3, 2021 - Accepted: May 1, 2021 
foram significativamente maiores quando comparados ao do bulbo. O extrato de etanol da casca de cebola também apresentou melhor atividade antioxidante e eliminação de radicais livres quando comparado ao extrato de etanol do bulbo, enquanto o extrato aquoso de bulbo apresentou menor potencial antioxidante. $O$ potencial de inibição da $\alpha$-glicosidase dos extratos de casca de cebola correlacionou-se com seus teores fenólicos e de flavonoides. Os resultados encontrados identificaram que a casca de cebola é uma possível fonte de agentes antioxidantes e compostos fenólicos que podem ser benéficos contra o desenvolvimento de várias doenças crônicas que estão associadas ao estresse oxidativo. Além disso, as camadas externas secas e as cascas da cebola exibiram maior conteúdo fenólico e atividades antioxidantes, em comparação com o bulbo interno. As informações obtidas pelo presente estudo podem promover o uso de outras partes vegetais além do mesocarpo comestível para futuras aplicações em alimentos, ao invés de serem desperdiçadas.

Palavras-chave: compostos bioativos, biorresíduos, flavonoides, estresse oxidativo, conteúdo fenólico.

\section{Introduction}

For decades, humans have been using naturally occurring indigenous plants including herbs, fruits and vegetables as therapies to various illnesses, But, over the course of time, the progress in advanced and effective technology along with development of synthetic drugs has prominently lowered the demand and popularity of the natural medicine approach. Other than several advantages, which includes commercial availability of allopathic medicines and their ready-to-use therapeutic applications, greater economic impacts and severe side effects are other alarming issues. Because of all these concerns, the traditional medicinal approach of using plants have been brought back into focus (Verma et al., 2007; Vasquez et al., 2014; Angell, 2004). Plants and herb-based extracts are regarded as better sources of functional nutrients that can aid in the prevention and management of certain non-communicable diseases (NCDs). Afterwards, the development of supplemented and functional foods from nutritious plant materials and enforcement of related medicinal applications are currently in focus (Isla et al., 2020).

Allium cepa (onion) has got great economic importance throughout the world as it is a common dietary item in most populations and is believed to be among the initially grown crops of world probably due to its greater shelf life and portability. Moreover, it has also been evaluated as a supple source of sulphur containing compounds, variety of flavonoids, and dietary fiber (Takahashi and Shibamoto, 2008). Likewise, the abundance of all these nutraceuticals contributes towards the maintenance and regulation of body functions (Bhattacharjee et al., 2013).

Tremendous amount of onion biowaste is generated on daily basis and it is estimated that annually 40 lac 500 thousand kilograms wastes of AIIium cepa is produced from Europe only (Benítez et al., 2011). The obtained derived items could serve as potent suppliers of certain chemical constituents that can be supplemented in regard to their suitable nutritional or technological assets (Masood et al., 2020). All that biowaste of onion that is widely generated from food processing of this vegetable either from household or industries, present an important problem of waste disposal for the concerned department (Schieber et al., 2001). Among the obtained byproducts of onion, dry peels and outer fleshy layers can provide plenty of bioactive compounds like quercetin, isorhamnetin and kaempferol (Celano et al., 2021) Moreover, they are also rich in fructans and various anthocyanins (Jaime et al., 2001).
The bulb and peel of onion can be used in management of hyperglycemia, cardiovascular disorders, endothelial dysfunction, hypercholesterolemia, fibrosis, platelet dysfunction and cancer (Oboh et al., 2019; Murayyan et al., 2017; Zeng et al., 2017). Various phenolics detected in Allium cepa might contribute in achieving these health promoting effects. Major flavonoid detected in Allium cepa is quercetin but along with it more than 16 other flavonols have also been identified which includes isorhamnetin and kaempferol that possess potent antioxidant properties and might be contributing towards the antioxidant effects and associated health benefits (Breu, 1996). Additionally, onion bulb has been previously reported to contain Ally propyl disulfides (APDS) as a major constituent, and along with this various other sulphur containing compounds are also present. During extraction, alliinase breaks down these S-allyl cysteine sulphoxides into several volatile compounds such as thiosulfinate and polysulfides. These constituents possess strong antidiabetic, hypocholesterolemic, antibiotic, fibrinolytic potential and can bring several other beneficial biological effects (Kowalczewski et al., 2020). However, stressful conditions like light and drought intensity (Kowalczewski et al., 2020; Vanacker et al., 2018), aphid feeding (Witkowska-Banaszczak et al., 2018), and even physical damage can promptly influence the antioxidant profile (Kowalczewski et al., 2019).

Antioxidant activity is related to medicinal ability of the extract against chronic diseases like cancer and diabetes in which it can help by inhibiting the action of certain important enzymes, which are linked with progression of these diseases. Like inside the gastrointestinal tract the absorption of dietary disaccharides like sucrose and maltose via intestine is done with the help of a group of $\alpha$-glucosidases like intestinal sucrase, isomaltase, maltase and glucoamylase. When activities of these enzymes are inhibited then it brings prominent reduction in the level of blood glucose after the consumption of carbohydrate rich meal and therefore can play a key role in the management of diabetes and its associated complications (Lamine et al., 2019).

Therefore, in current research we assessed and compared the antioxidant and enzyme inhibiting potential of onion peel and bulb extracts to find new potential sources of natural antioxidants and also investigated the potential relationship between antioxidant activity and $\alpha$-glucosidases $/ \alpha$-amylase inhibitory activity. 


\section{Materials and Methods}

Good quality and undamaged onions (Var. Desi Red, Phulkara) were obtained from a local market in Lahore, Pakistan. 1,1-diphenyl-2-picrylhydrazyl (DPPH), $\mathrm{Na} 2 \mathrm{CO} 3, \mathrm{MeOH}, \mathrm{AlCl} 3$, Folin-Ciocalteu's phenol reagent, potassium ferricyanide, potassium persulfate (K2S2O8), trichloroacetic acid, 2,2'-azino-bis (3- ethylbenzothiazoline6-sulfonic acid) (ABTS), ferrozine ferric chloride, $\mathrm{FeCl} 2$, hydrogen peroxide $\left(\mathrm{H}_{2} \mathrm{O}_{2}\right)$, Peroxidase from horseradish. A-glucosidase (EC3-2.1.20) and $\alpha$-amylase (EC-3.2.1.1) were bought from Sigma-Aldrich (St. Louis, MO, USA).

\subsection{Sample preparation}

Onions were washed thoroughly, and their peels and bulbs were separated. Afterwards, $50 \mathrm{~g}$ of onion pulp or peel was mixed separately in $250 \mathrm{~mL}$ of solvent (water or ethanol) and then kept for 24 hours inside a shaking incubator at $25^{\circ} \mathrm{C}$. Using Whatman filter paper, the mixture was filtered, and the obtained filtrate was evaporated by rotary vacuum evaporator to obtain the final extract which was sealed in dark colored bottles and kept in fridge till analysis.

\subsection{Total phenolic content}

The content of phenols was assessed by modifying the protocol of Shetty et al. (1995). For this purpose, one mL of onion bulb or peel extract was thoroughly mixed with $5 \mathrm{~mL}$ of distilled water along with $1 \mathrm{~mL}$ of $95 \%$ ethanol inside a test tube. Later Folin-Ciocalteu reagent $(0.5 \mathrm{~mL}$ of $50 \%$ $(\mathrm{v} / \mathrm{v})$ ) was separately added to every sample and mixed. After duration of 5 minutes, $1 \mathrm{~mL}$ of $\mathrm{Na} 2 \mathrm{CO} 3$ (5\%) was mixed in solution and afterwards, it was allowed to stand for 1 hour. Spectrophotometer (UV-160A; Shimadzu Inc., Kyoto, Japan) was used to measure absorbance at $725 \mathrm{~nm}$.

\subsection{Total flavonoid content}

The total flavonoids contents of Allium cepa peel and bulb extract was estimated by following the aluminum chloride colorimetric method (Woisky and Salatino, 1998). Initially, the prepared bulb and peel extracts of onion were separately added in methanol $(1 \mathrm{mg} / \mathrm{mL})$ and the reaction mixture $(0.5 \mathrm{~mL})$ was dissolved with $1.5 \mathrm{~mL}$ of $95 \%$ ethanol, $2.8 \mathrm{~mL}$ of distilled water, $0.1 \mathrm{~mL}$ of $1 \mathrm{M}$ potassium acetate and $0.1 \mathrm{~mL}$ of $10 \%$ aluminum chloride. Then the solution was incubated at $25^{\circ} \mathrm{C}$ for duration of 30 minutes and at $415 \mathrm{~nm}$, the absorbance was taken. As a standard Quercetin (HPLC grade; Sigma- Aldrich) was used in order to formulate the calibration curve.

\subsection{DPPH free radical scavenging activity}

The method of Blois with slight modifications was used to evaluate the free radical scavenging activity of each sample (Blois, 1958). For this, $5 \mathrm{~mL}$ of DPPH (0.1 mM) prepared in ethanol (95\%) was separately added to every extract sample $(1 \mathrm{~mL})$ that was previously diluted tenfold. The prepared mixture was then put over the orbital shaker for 15 minutes and later incubated in dark at $25^{\circ} \mathrm{C}$ for half hour. Afterwards, nylon syringe $(0.4 \mathrm{~lm})$ filter was used to obtain the filtrate and at $517 \mathrm{~nm}$ the absorbance was taken.
The following Equation 1 as used for the calculation:

$D P P H$ radical scavenging effect $(\%)=$

$\{1-($ absorbance sample / absorbance control $)\} \times 100$

\subsection{FRAP assay}

The method of Oyaizu was used to conduct the FRAP assay (Oyaizu, 1986) in which, $1 \mathrm{~mL}$ of each extract sample that was diluted tenfold was thoroughly mixed with $2.5 \mathrm{~mL}$ of $1 \%$ potassium ferricyanide (potassium hexacyanoferrate) and $2.5 \mathrm{~mL}$ of sodium phosphate buffer (0.2 M, pH 6.6). The obtained mixture was then incubated for 20 minutes at $50{ }^{\circ} \mathrm{C}$. Afterwards, $2.5 \mathrm{~mL}$ of $10 \%$ trichloroacetic acid was added and the mixture was put inside centrifuge for 10 minutes at $4000 \mathrm{rpm}$. $2.5 \mathrm{ml}$ of topmost layer was mixed with similar quantity of distilled water along with $0.5 \mathrm{~mL}$ of $0.1 \% \mathrm{FeCl} 3$ (ferric chloride). The reaction was allowed to complete for 5 minutes at $25^{\circ} \mathrm{C}$ and at $700 \mathrm{~nm}$ the absorbance reading was taken.

\subsection{Ferrous ions $\left(\mathrm{Fe}^{2+}\right)$ chelating activity}

$\mathrm{Fe}^{2+}$ chelating activity of the onion peel and bulb extract was evaluated using the published protocol (Dinis et al., 1994). For this, $0.5 \mathrm{~mL}$ of each of the extract that was previously diluted tenfold, was thoroughly mixed with $2 \mathrm{~mL}$ of ferrous chloride $(1 \mathrm{mM})$ prepared in $95 \%$ ethanol. After addition of $2.5 \mathrm{~mL}$ of $2 \mathrm{~mm}$ ferrozine in the ethanol, the reaction was initiated. The vortexed mixture was then incubated at $25^{\circ} \mathrm{C}$ for the duration of 10 minutes and filtered later through a $0.45 \mu \mathrm{m}$ nylon syringe filter. At $562 \mathrm{~nm}$, the absorbance of the filtrate was noted.

The chelating activity of Ferrous ions was then calculated using the following Equation 2:

$$
\begin{aligned}
& \text { Ferrous ions chelating activity }(\%)= \\
& \{1-(\text { absorbance sample / absorbance control })\} \times 100
\end{aligned}
$$

\subsection{ABTS radical scavenging activity assay}

Protocol elaborated by (Re et al., 1999) was used in the evaluation of ABTS radical scavenging activity. In order to obtain the green-blue free radicals of ABTS+, a mixture of $15 \mathrm{~mL}$ of ABTS ( $7 \mathrm{mM}$ ) and potassium persulfate [15 ml (2.45 mM)] was stored in dark for duration of 16 hours at $25{ }^{\circ} \mathrm{C}$. Later dilution of the solution was done using ethanol till the recorded absorbance was $0.7 \pm 0.02$ at $734 \mathrm{~nm} .0 .1 \mathrm{ml}$ of the prepared extract samples were incorporated and mixed with $2.9 \mathrm{~mL}$ of ABTS working solution and after 10 minutes of reaction, the absorbance was measured at $734 \mathrm{~nm}$ while the ascorbic acid was used as control for calibration. Formula 3 used for calculation is as follows.

$$
\begin{aligned}
& \text { ABTS + radical scavenging effect }(\%)= \\
& \{1-(\text { absorbance sample / absorbance control })\} \times 100
\end{aligned}
$$




\subsection{Hydrogen peroxide $\left(\mathrm{H}_{2} \mathrm{O}_{2}\right)$ scavenging activity}

The scavenging activity of Hydrogen peroxide was evaluated using the established protocol (Okamoto et al., 1992). For that purpose, each of the prepared extract sample $(0.1 \mathrm{~mL})$ was thoroughly mixed with $0.01 \mathrm{ml} \mathrm{of} \mathrm{H}_{2} \mathrm{O}_{2}$ $(50 \mathrm{mM}), 0.6 \mathrm{~mL}$ peroxidase from horseradish $(10 \mathrm{U} / \mathrm{mL})$, $0.6 \mathrm{~mL}$ of $0.1 \%$ ABTS, and $1.8 \mathrm{~mL}$ of phosphate buffer $(0.1 \mathrm{M})$ which was calibrated at $\mathrm{pH}$ 6.0. The prepared mixture was then incubated for duration of 15 minutes at $37{ }^{\circ} \mathrm{C}$. Using spectrophotometer, the absorbance of the solution was calibrated and measured at $414 \mathrm{~nm}$ while gallic acid equivalents were used to design the standard curve.

\section{9. $\alpha$-Amylase inhibition assay}

Protocol described by Kwon et al. (2006) was used for evaluation of $\alpha$-Amylase inhibition assay. $200 \mu \mathrm{L}$ of prepared extract solution was mixed with $500 \mu \mathrm{L}$ of $0.02 \mathrm{M}$ sodium phosphate buffer ( $\mathrm{pH} 6.9$ with $0.006 \mathrm{M}$ sodium chloride) which was containing $0.5 \mathrm{mg} / \mathrm{mL}$ of $\alpha$-amylase solution $(0.5 \mathrm{mg} / \mathrm{mL})$ and the mixture was incubated at $25{ }^{\circ} \mathrm{C}$ for the duration of 10 minutes. When pre-incubation was over, $1 \%$ starch solution $(500 \mu \mathrm{L})$ mixed in $0.02 \mathrm{M} \mathrm{NaH} 2 \mathrm{PO} 4$ buffer was added in the solution. The entire reaction mixture was again kept for incubation at $25^{\circ} \mathrm{C}$ for $10 \mathrm{~min}$. After addition of $1 \mathrm{~mL}$ of dinitrosalicylic (DNS) acid, the reaction stopped and the mixture was later incubated for $5 \mathrm{~min}$ in a boiling water bath and then cooled at $25^{\circ} \mathrm{C}$. Dilution of the reaction mixture was done after addition of $10 \mathrm{~mL}$ of distilled water, and then using enzyme-linked immunosorbent assay (ELISA) the absorbance was measured at $540 \mathrm{~nm}$ with micro plate reader (SUNRISE; Tecan Trading AG). Formula 4 used for calculating \% inhibition is as follows.

$$
\% \text { inhibition }=\left\{\begin{array}{l}
\left(\begin{array}{l}
\text { absorbance control }- \text { absorbance sample }) \\
\text { /absorbance control })
\end{array}\right.
\end{array}\right\} \times 100
$$

\subsection{0. $\alpha$-Glucosidase inhibition assay}

$\alpha$-glucosidase inhibition assay of rat's intestine was done by referring to the protocol elaborated by Kwon et al. (2006) with little changes. For this purpose, $3 \mathrm{~mL}$ of $0.9 \%$ saline was used to make suspension of one gram of rat-intestinal acetone powder which was then sonicated 12 times at $4{ }^{\circ} \mathrm{C}$ for the duration of $30 \mathrm{sec}$. The resulting supernatant obtained after centrifugation $\left(30 \mathrm{~min}, 4^{\circ} \mathrm{C}\right.$, $10,000 \times \mathrm{g}$,), was used for the assay. The prepared $50 \mu \mathrm{L}$ of sample solution and $1.0 \mathrm{U} / \mathrm{mL}$ of $\alpha$-glucosidase solution dissolved in $100 \mu \mathrm{L}$ of phosphate buffer $(0.1 \mathrm{M})$ adjusted to $\mathrm{pH} 6.9$, was incubated at temperature of $25^{\circ} \mathrm{C}$ for the duration of 10 minutes. When the pre-incubation was over, the addition of $5 \mathrm{mM}$ p-nitrophenyl- $\alpha$-D-glucopyranoside $(50 \mu \mathrm{L})$ solution dissolved inside $0.1 \mathrm{M}$ phosphate buffer was done after a particular time interval in each well. Mixture was then kept for incubation for the duration of 5 minutes at room temperature. The absorbance was evaluated at $405 \mathrm{~nm}$ before and after the incubation and the results were compared with the control in which $50 \mu \mathrm{L}$ of buffer solution was present instead of the extract sample. Inhibitory activity of $\alpha$-glucosidase was expressed as inhibition \% and the calculation of it is as follows (Equation 5).

$$
\% \text { inhibition }=\left\{\begin{array}{l}
\left(\begin{array}{l}
\text { absorbance control }- \text { absorbance sample }) / \\
\text { absorbance control })
\end{array}\right.
\end{array}\right\} x 100
$$

\subsection{Statistical analysis}

All experiments were carried out in triplicates. Results are presented as mean \pm standard deviation. One-way analysis of variance (ANOVA) and a posthoc Tukey HSD comparison was performed. A p-value of less than 0.05 was considered statistically significant. Data was analyzed and figures were prepared by using GraphPad Prism version 8.0.2 (Motulsky, 2020).

\section{Results and Discussion}

\section{1. $\alpha$-Amylase/ $\alpha$-glucosidase inhibition of onion extracts}

Inside the villi region of small intestine, the enzyme $\alpha$-glucosidase works towards the release of D-glucose units from disaccharides as well as oligosaccharides and any substance that can inhibit this enzymatic activity could serve in reducing glucose absorption rate which in turn lowers down postprandial plasma glucose levels (Bischoff, 1994). Several researches conducted on plants and herbs which contain phenolics in abundant quantities have reported a link between antioxidant activity of extract and inhibition of $\alpha$-glucosidase activity (Kwon et al., 2006) and particularly Allium cepa bulb have been evaluated for it's several physiological effects including anti-diabetic properties (Wu and Xu, 2011). But for onion outer skin and peels very few studies have investigated their anti-diabetic potential even though they present great concentrations of phytochemicals (Masood et al., 2021). It was stated that methyl alcohol extracts of Allium cepa. had potent ability to inhibit $\alpha$-glucosidase activity (Lee et al., 2008). In order to have better understanding of onion's antioxidant potential, the glucosidase inhibitory activity of bulb and peel extract were evaluated and compared in this study. Ethanolic extract of onion peel reported greater inhibition potential as compared to the ethanolic bulb extract being $80 \%$ vs $40 \%$ respectively which is in accordance with the previously published studies (Kim et al., 2010) while, water extract of bulb reported the lowest activity. The comparative analysis of $\alpha$-glucosidase and $\alpha$-amylase inhibition potential of various extracts was also done and it was revealed that the onion bulb and peel extracts caused prominent $\alpha$-glucosidase inhibition but depicted significantly lower potential against inhibition of $\alpha$-amylase (see Figure 1E, F). In previous studies, $\alpha$-amylase and $\alpha$-glucosidase inhibition mechanism of several phenolic compounds and quercetin in particular which is the major flavonoid of onion has been thoroughly investigated (Chen et al., 2020; Nile et al., 2021).

The findings of earlier studies indicated quercetin acting with as mixed close to non-competitive inhibition type, which highlights that this compound can bind with both enzyme-substrate complex as well as free enzyme 
whereas its 3-OH glycosylated derivatives can vary their inhibitory mechanism towards competitive inhibition as well (Nile et al., 2021; Li et al., 2009) The substitution of hydroxyl group on B-ring of C3(A)-C6(C)-C3(B) and third hydroxyl group of the C-ring in flavanols might have contributed towards increasing the $\alpha$-glucosidase inhibition potential (Tadera et al., 2006). As quercetin is present in much higher concentrations in onion peel as compared to its bulb (Yoo et al., 2013), this might be a responsible factor behind our obtained results. The current findings highlight that onion extracts can serve as strong $\alpha$-glucosidase inhibitors and concentration of phenols in an extract might serve as a central factor while determining the inhibition potential of $\alpha$-glucosidase as the inhibitory activities of the extracts were correlating with total phenolic content and overall antioxidant activity of respective extracts.

\subsection{Determination of total phenolic and flavonoid content of extracts}

The findings of phenolic as well as flavonoid content of onion peel and onion bulb extracts is presented (as shown in Table 1). Ethanolic extract of onion peel reported total phenolic content of $147.33 \mathrm{mg} \mathrm{GAE} / \mathrm{g}$ which was significantly higher $(p<0.05)$ as compared to the other extract samples. While comparing the TPC values, the following order was observed: [OP_E (147.33 mg GAE/g), OP_W (89 mg GAE/g)], [OB_E (43 mg GAE/g), OB_W $26 \mathrm{mg} \mathrm{GAE} / \mathrm{g}$ ]. Generally, the antioxidant potential of a particular plant or herb is in association with the TPC content (Cai et al., 2004). In terms of the flavonoid content, onion peel scored better than onion bulb regardless of the type of solvent used. Particularly the flavonoid content of ethanol-based onion peel extract was nearly twice of onion
(A)

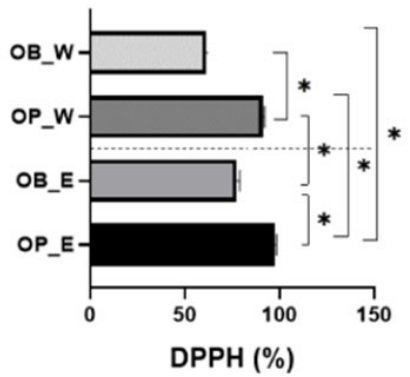

(D)

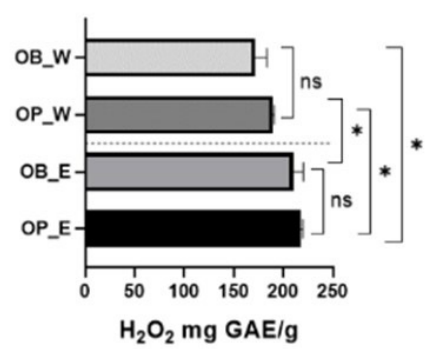

(B)

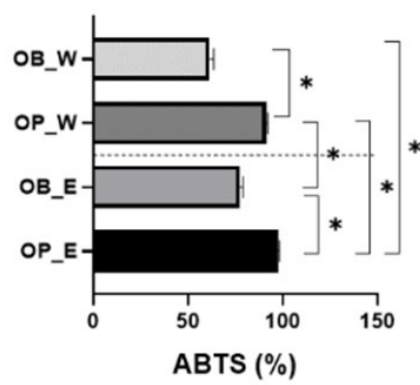

(E)

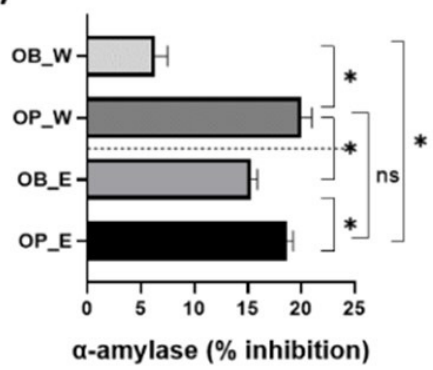

(C)

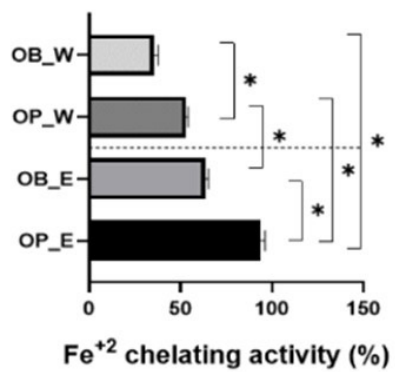

(F)

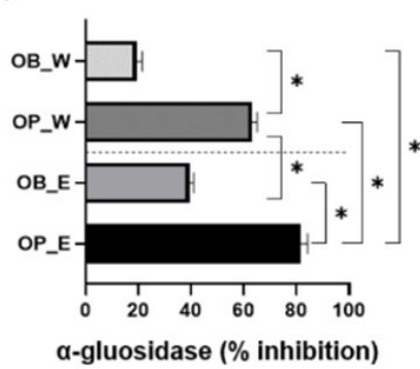

Figure 1. Comparison of phenolic and antioxidant activity of onion peel (OP) and onion bulb (OB) extracts prepared by ethanol (E) and water (W). (A) DPPH; 2,2-diphenyl-1-picrylhydrazyl in (\%); (B) ABTS; 2,2'-azino-bis- 3-ethylbenzothiazoline-6-sulfonic acid (\%); (C) $\mathrm{Fe}^{2+}$ chelating activity (\%); (D) $\mathrm{H}_{2} \mathrm{O}_{2}$ radical scavenging activity (mg GAE/g); (E) $\alpha$-Amylase inhibition (\%); (F) $\alpha$-Glucosidase inhibition (\%). *shows significant difference among pairs of samples $(\mathrm{p}<0.05)$ in terms of Tukey HSD.

Table 1. Mean comparison for total phenolic content (TPC) and total flavonoid content (TFC) in Onion peel and Onion bulb with two extraction methods.

\begin{tabular}{|c|c|c|c|c|c|c|}
\hline $\begin{array}{l}\text { Tukey's multiple } \\
\text { comparisons (1 vs } 2 \text { ) }\end{array}$ & Mean TPC 1 & Mean TPC 2 & $\begin{array}{c}\text { Mean Diff. TPC } \\
\text { (mg/g GAE) }\end{array}$ & Mean TFC 1 & Mean TFC 2 & $\begin{array}{l}\text { Mean Diff. } \\
\text { TFC (mg of } \\
\text { quercetin/g) }\end{array}$ \\
\hline OP_E vs. OB_E & 147.3 & 43.33 & $103.97^{*}$ & 72.33 & 26.33 & $46.00^{*}$ \\
\hline OP_E vs. OP_W & 147.3 & 89.67 & $57.63^{*}$ & 72.33 & 40.33 & $32.00^{*}$ \\
\hline OP_E vs. OB_W & 147.3 & 26.33 & $120.97^{*}$ & 72.33 & 15.67 & $56.66^{*}$ \\
\hline OB_E vs. OP_W & 43.33 & 89.67 & $-46.34^{*}$ & 26.33 & 40.33 & $-14.00^{*}$ \\
\hline OB_E vs. OB_W & 43.33 & 26.33 & $17.00^{*}$ & 26.33 & 15.67 & $10.66^{*}$ \\
\hline OP_W vs. OB_W & 89.67 & 26.33 & $63.34^{*}$ & 40.33 & 15.67 & $24.66^{*}$ \\
\hline
\end{tabular}

Where, $\mathrm{OP}=$ onion peel; $\mathrm{OB}=$ onion bulb; $\mathrm{E}=$ extract with ethanol; $\mathrm{W}=$ extract with water. ${ }^{*}$ shows significance at $(\mathrm{p}<0.01)$ for Tukey HSD comparison. 
bulb (OP_E=72 mg QE/g; OB_E= $27 \mathrm{mg} Q \mathrm{QE} / \mathrm{g}$ ) and was also fairly high as compared to the other water-based extracts as well. The possible reason might be the presence of high levels of quercetin in onion fleshy peels and dry skin as compared to that of bulb. Quercetin is the most abundant phenol found in onion and Kim and Kim (2006) reported that quercetin concentration in the methanolic extract of onion dry scales, outer skin, middle layers and inner core was $16.83,2.67,0.95$, and $0.35 \mathrm{mg} / \mathrm{g}$ respectively which highlights that quercetin concentration decreases from outside towards the core. All these findings highlight the strong antioxidant potential of onion peel extract and paves way for incorporating such extracts in food products for enhancing their nutraceutical value.

\subsection{DPPH and ABTS radical scavenging activity}

The DPPH radical scavenging activity of ethanol-based extracts was better as compared to their respective waterbased extracts: [OP_E(77.33\%), OB_E(45\%)] [OP_W(62.66\%), OB_W (31.66\%)] (see Figure 1A). Onion peels extracted via ethanol reported prominently greater potential $(\mathrm{p}<0.05)$ as compared to the ethanolic bulb extracts. The results of ABTS radical scavenging activity were also in relation to that of DPPH radial scavenging test. i.e., onion peel extracts had higher activity when compared with the onion bulb extracts and the ethanol-based extract of onion peel got the highest score (see Figure 1B). Onion bulb groups displayed a decreasing tendency based on the extraction solvent (Ethanol > water). The results of ABTS radical cation scavenging activity were in the following order. [OP_E (97.66\%), OP_W (91.33\%)] [OB_E (77.33\%), OB_W (61.33\%)]. Earlier study have demonstrated that onion peel and dry scales possess plentiful phenolic compounds and flavonoids as compared to that of bulb (Kim et al., 2010). The concentration of all those nutraceuticals have positive link with ABTS and DPPH radical scavenging activities because of their potential to give electrons from their hydroxyl groups in order to reduce the potential oxidative stress (Brand-Williams et al., 1995; Rice-Evans et al., 1996). For evaluating antioxidant potential, ABTS is considered to be potentially more effective as compared to DPPH method as the previous one can measure hydrophobic substances along with the hydrophilic ones (Martysiak-Żurowska and Wenta, 2012; Camargo et al., 2016).

In Allium cepa varieties, generally the most abundant flavonoids are the flavanol aglycones like quercetin (Rodríguez Galdón et al., 2009). It has been reported that presence of multiple hydroxyl groups in flavonoids increases their antioxidant potential against peroxyl radicals (Vu et al., 2020; Benites et al., 2015). The obtained values might be due to the high concentration of quercetin which is more abundant in peel as compared to bulb and quercetin can also contribute in reducing peroxyl radicals by donating electrons to complete their valency and improve the stability of free radicals. Other studies have also reported strong radical scavenging potential of quercetin and onion extracts (Lue et al., 2010; Ye et al., 2013). The greater antioxidant potential of onion peel's ethanolic extract indicates towards its possible role in the prevention of oxidative degradation of lipid bilayer of cell membranes which is quite relevant in terms of prevention of chronic diseases development.

\subsection{Ferric reducing antioxidation power (FRAP)}

This method can evaluate the antioxidant potential of an extract by assessing its electron donating ability. In this, antioxidants present in extract sample have the ability to reduce ferric tripyridyltriazine (Fe3+TPTZ) into ferrous tripyridyltriazine ( $\mathrm{Fe}^{2+} \mathrm{TPTZ}$ ). Higher absorbance might indicate towards greater antioxidant activity (Abdelaleem and Elbassiony, 2021). The obtained results of ferric reducing power depicted that onion peel samples have decreasing tendency of reduction based on the kind of solvent used for extraction (i.e., ethanol or water) when absorbance was measured at 700nm (see Figure 2). Among the extract samples, onion peel ethanolic extract got significantly $(\mathrm{p}<0.05)$ greater values as compared to the other samples. Reduction tendency of those extracts had the following order: OP_E $>$ OP_W $>O B \_E>O B \_W$. The obtained results might indicate towards higher concentration of phenols and flavonoids in ethanolic extracts as compared to water. Positive link among polyphenol \& flavonoid concentration of Allium species and Ferric reducing antioxidation power value $(r 2=0.669)$ has been reported previously (Nencini et al., 2011).

\subsection{Ferrous ions $\left(\mathrm{Fe}^{2+}\right)$ chelating activity}

The complex formed due to reaction of ferrozine with $\mathrm{Fe}^{2+}$ is responsible for the development of purple color. Chelating activity of the antioxidants present inside extract can eventually prevent development of ferrozine $\mathrm{Fe}^{2+}$ complex, which ultimately results in colour degradation. As shown in Figure 1C it can be seen that all types of extracts depicted some extent of ferrous ions chelating activity. Particularly, extracts that were prepared with ethanol performed significantly $(\mathrm{p}<0.05$ ) better as compared to other extracts that were prepared using water. Similarly,

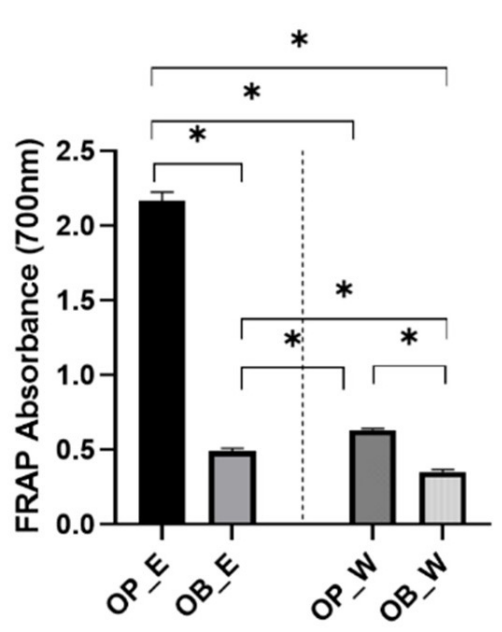

Figure 2. Comparison of ferric-reducing antioxidant power assay (FRAP) of onion peel (OP) and onion bulb (OB) extracts prepared by ethanol (E) and water $(\mathrm{W})$. * shows significant difference among pairs of samples $(p<0.05)$ in terms of Tukey HSD. 
Lee et al reported that ethanolic extract from onion has greater metal chelating and radical scavenging activity than aqueous extracts (Lee et al., 2014). The potent ability of onion extracts to inhibit Fe2+ lipid oxidation rate has been reported previously (Prakash et al., 2007). Possible reason behind the greater potential of ethanol extracts might be because of thiol groups like that of hydrophobic disulfides which possess strong metal chelating properties (Saha et al., 2000).

\subsection{Hydrogen peroxide $\left(\mathrm{H}_{2} \mathrm{O}_{2}\right)$ scavenging activity}

As shown in Figure 1D, the obtained results of hydrogen peroxide scavenging activities of onion peel and onion bulb extracts are presented. Onion peel extracted via ethanol depicted the highest potential to scavenge hydrogen peroxide (217.66 $\mathrm{mg} \mathrm{GAE} / \mathrm{g}$ ) which was followed by OP_W (189 mg GAE/g), OB_E (172.33 mg GAE/g), OB_W (146.66 mg GAE/g)]. Ethanolic extracts performed better than water extracts but no significant differences were observed among extracts prepared from similar solvent.

Generally, hydrogen peroxide is not considered to be linked with greater free radical production. But when some metal ions like $\mathrm{Cu} 2+, \mathrm{Fe}^{2+}$ are present it does present higher risk of toxicity. Onion extracts can also potentially inhibit the peroxidation of lipids caused by generation of $\mathrm{Fe}^{2+}$ and hydrogen peroxide (Jaiswal and Ibrahim Rizvi, 2012). The hydrogen peroxide scavenging potential of sulfur containing compounds such as SAC and alliin that are present in Allium family vegetables have been reported (Ide et al., 1996). Moreover, Javier Moreno et al. (2006) have reported that fructosyl arginine generated from Maillard reaction in onions also possess strong hydrogen peroxide scavenging ability. Hence, the strong potential of onion peel extract that was prepared using ethanol might be beneficial in providing protection from oxidative toxicity.

\section{Acknowledgements}

We cordially thank Marcia de Oliveira Franco from Natural Resources Institute (Luke), Finland for assisting with translation of abstract and keywords

\section{References}

ABDELALEEM, M.A. and ELBASSIONY, K.R.A., 2021. Evaluation of phytochemicals and antioxidant activity of gamma irradiated quinoa (Chenopodium quinoa). Brazilian Journal of Biology = Revista Brasileira de Biologia, vol. 81, no. 3, pp. 806-813. http:// dx.doi.org/10.1590/1519-6984.232270. PMid:32965339.

ANGELL, M., 2004. Excess in the pharmaceutical industry. Canadian Medical Association Journal, vol. 171, no. 12, pp. 1451-1453. http:// dx.doi.org/10.1503/cmaj.1041594. PMid:15583183.

BENITES, R.S.R., FORMAGIO, A.S.N., ARGANDOÑA, E.J.S., VOLOBUFF, C.R.F., TREVIZAN, L.N.F., VIEIRA, M.C. and SILVA, M.S., 2015. Contents of constituents and antioxidant activity of seed and pulp extracts of Annona coriacea and Annona sylvatica. Brazilian Journal of Biology = Revista Brasileira de Biologia, vol. 75, no. 3, pp. 685-691. http://dx.doi.org/10.1590/1519-6984.21313. PMid:26421762.
BENÍTEZ, V., MOLLÁ, E., MARTÍN-CABREJAS, M.A., AGUILERA, Y., LÓPEZ-ANDRÉU, F.J., COOLS, K., TERRY, L.A. and ESTEBAN, R.M., 2011. Characterization of industrial onion wastes (Allium cepa L.): dietary fibre and bioactive compounds. Plant Foods for Human Nutrition, vol. 66, no. 1, pp. 48-57. http://dx.doi.org/10.1007/ s11130-011-0212-x. PMid:21318305.

BHATTACHARJEE, S., SULTANA, A., SAZZAD, M.H., ISLAM, M.A., AHTASHOM, M. and ASADUZZAMAN, M., 2013. Analysis of the proximate composition and energy values of two varieties of onion (Allium cepa L.) bulbs of different origin: A comparative study. International Journal of Nutrition and Food Sciences, vol. 2, no. 5, pp. 246-253. http://dx.doi.org/10.11648/j. ijnfs.20130205.16.

BISCHOFF, H., 1994. Pharmacology of alpha-glucosidase inhibition. European Journal of Clinical Investigation, vol. 24, no. 53, suppl. 3, pp. 3-10. http://dx.doi.org/10.1111/j.1365-2362.1994.tb02249.x. PMid:8001624.

BLOIS, M.S., 1958. Antioxidant determinations by the use of a stable free radical. Nature, vol. 181, no. 4617, pp. 1199-1200. http:// dx.doi.org/10.1038/1811199a0.

BRAND-WILLIAMS, W., CUVELIER, M.E. and BERSET, C.L.W.T., 1995. Use of a free radical method to evaluate antioxidant activity. Lebensmittel-Wissenschaft + Technologie, vol. 28, no. 1, pp. 25-30. http://dx.doi.org/10.1016/S0023-6438(95)80008-5.

BREU, W., 1996. Allium cepa L.(onion) part 1: chemistry and analysis. Phytomedicine, vol. 3, no. 3, pp. 293-306. http:// dx.doi.org/10.1016/S0944-7113(96)80069-9. PMid:23195086.

CAI, Y., LUO, Q., SUN, M. and CORKE, H., 2004. Antioxidant activity and phenolic compounds of 112 traditional Chinese medicinal plants associated with anticancer. Life Sciences, vol. 74, no. 17, pp. 2157-2184. http://dx.doi.org/10.1016/j.lfs.2003.09.047. PMid:14969719.

CAMARGO, L.E.A., PEDROSO, L.S., VENDRAME, S.C., MAINARDES, R.M. and KHALIL, N.M., 2016. Antioxidant and antifungal activities of Camellia sinensis (L.) Kuntze leaves obtained by different forms of production. Brazilian Journal of Biology = Revista Brasileira de Biologia, vol. 76, no. 2, pp. 428-234. http://dx.doi. org/10.1590/1519-6984.18814. PMid:26983085.

CELANO, R., DOCIMO, T., PICCINELLI, A.L., GAZZERRO, P., TUCCI, M., DI SANZO, R., CARABETTA, S., CAMPONE, L., RUSSO, M. and RASTRELLI, L., 2021. Onion peel: turning a food waste into a resource. Antioxidants, vol. 10, no. 2, pp. 304. http://dx.doi. org/10.3390/antiox10020304. PMid:33669451.

CHEN, J.G., WU, S.F., ZHANG, Q.F., YIN, Z.P. and ZHANG, L., 2020. $\alpha$-Glucosidase inhibitory effect of anthocyanins from Cinnamomum camphora fruit: inhibition kinetics and mechanistic insights through in vitro and in silico studies. International Journal of Biological Macromolecules, vol. 143, pp. 696-703. http://dx.doi.org/10.1016/j.ijbiomac.2019.09.091. PMid:31521662.

DINIS, T.C., MADEIRA, V.M. and ALMEIDA, L.M., 1994. Action of phenolic derivatives (acetaminophen, salicylate, and 5-aminosalicylate) as inhibitors of membrane lipid peroxidation and as peroxyl radical scavengers. Archives of Biochemistry and Biophysics, vol. 315, no. 1, pp. 161-169. http://dx.doi.org/10.1006/ abbi.1994.1485. PMid:7979394.

IDE, N., MATSUURA, H. and ITAKURA, Y., 1996. Scavenging effect of aged garlic extract and its constituents on active oxygen species. Phytotherapy Research, vol. 10, no. 4, pp. 340-341. https://doi.org/10.1002/(SICI)1099-1573(199606)10:4<340::AIDPTR831>3.0.CO;2-4.

ISLA, M.I., CATTANEO, F., ORQUEDA, M.E., MORENO, M.A., PÉREZ, J., RODRÍGUEZ, I.F., URIBURU, F.M.C., TORRES, S. and ZAMPINI, 
I.C., 2020. Potential application of native fruit wastes from Argentina as nonconventional sources of functional ingredients. In: Z.A. ZAKARIA, C.N. AGUILAR, R.D. KUSUMANINGTYAS and P. BINOD, eds. Valorisation of agro-industrial residues - Volume II: non-biological approaches. Cham: Springer, pp. 173-190. http:// dx.doi.org/10.1007/978-3-030-39208-6_8.

JAIME, L., MARTÍNEZ, F., MARTIIN-CABREJAS, M. A., MOLLÁ, E., LÓPEZANDRÉU, F.J., WALDRON, K.W. and ESTEBAN, R.M., 2001. Study of total fructan and fructooligosaccharide content in different onion tissues. Journal of the Science of Food and Agriculture, vol. 81, no. 2, pp. 177-182. http://dx.doi.org/10.1002/10970010(20010115)81:2<177::AID-JSFA796>3.0.CO;2-9.

JAISWAL, N. and IBRAHIM RIZVI, S., 2012. Variation of antioxidant capacity in different layers of onion (Allium cepa L.) at two different stages of maturation. Current Nutrition and Food Science, vol. 8, no. 2, pp. 126-130. http://dx.doi. org/10.2174/157340112800840763.

JAVIER MORENO, F., CORZO-MARTI’NEZ, M., DOLORES DEL CASTILLO, M. and VILLAMIEL, M., 2006. Changes in antioxidant activity of dehydrated onion and garlic during storage. Food Research International, vol. 39, no. 8, pp. 891-897. http://dx.doi. org/10.1016/j.foodres.2006.03.012.

KIM, M.H., JO, S.H., JANG, H.D., LEE, M.S. and KWON, Y.I., 2010. Antioxidant activity and $\alpha$-glucosidase inhibitory potential of onion (Allium cepa L.) extracts. Food Science and Biotechnology, vol. 19, no. 1, pp. 159-164. http://dx.doi.org/10.1007/s10068010-0022-1.

KIM, S.J. and KIM, G.H., 2006. Quantification of quercetin in different parts of onion and its DPPH radical scavenging and antibacterial activity. Food Science and Biotechnology, vol. 15, no. 1, pp. 39-43.

KOWALCZEWSKI, P.Ł., OLEJNIK, A., BIAŁAS, W., KUBIAK, P., SIGER, A., NOWICKI, M. and LEWANDOWICZ, G., 2019. Effect of thermal processing on antioxidant activity and cytotoxicity of waste potato juice. Open Life Sciences, vol. 14, no. 1, pp. 150-157. http:// dx.doi.org/10.1515/biol-2019-0017. PMid:33817147.

KOWALCZEWSKI, P.Ł., RADZIKOWSKA, D., IVANIŠOVÁ, E., SZWENGIEL, A., KAČÁNIOVÁ, M. and SAWINSKA, Z., 2020. Influence of Abiotic Stress Factors on the Antioxidant Properties and Polyphenols Profile Composition of Green Barley (Hordeum vulgare L.). International Journal of Molecular Sciences, vol. 21, no. 2, pp. 397. http://dx.doi.org/10.3390/ijms21020397. PMid:31936315.

KWON, Y.I.I., VATTEM, D.A. and SHETTY, K., 2006. Evaluation of clonal herbs of Lamiaceae species for management of diabetes and hypertension. Asia Pacific Journal of Clinical Nutrition, vol. 15, no. 1, pp. 107-118. PMid:16500886.

LAMINE, J.B., BOUJBIHA, M.A., DAHANE, S., CHERIFA, A.B., KHLIFI, A., CHAHDOURA, H., YAKOUBI, M.T., FERCHICHI, S., EL-AYEB, N. and ACHOUR, L., 2019. A-amylase and $\alpha$-glucosidase inhibitor effects and pancreatic response to diabetes mellitus on wistar rats of ephedra alata areal part decoction with immunohistochemical analyses. Environmental Science and Pollution Research International, vol. 26, no. 10, pp. 9739-9754. http://dx.doi.org/10.1007/s11356-019-04339-3. PMid:30729433.

LEE, K.A., KIM, K.T., KIM, H.J., CHUNG, M.S., CHANG, P.S., PARK, H. and PAI, H.D., 2014. Antioxidant activities of onion (Allium cepa L.) peel extracts produced by ethanol, hot water, and subcritical water extraction. Food Science and Biotechnology, vol. 23, no. 2, pp. 615-621. http://dx.doi.org/10.1007/s10068-014-0084-6.

LEE, S.K., HWANG, J.Y., KANG, M.J., KIM, Y.M., JUNG, S.H., LEE, J.H. and KIM, J.I., 2008. Hypoglycemic effect of onion skin extract in animal models of diabetes mellitus. Food Science and Biotechnology, vol. 17, no. 1, pp. 130-134. http://dx.doi. org/10.1002/jsfa.8323.
LI, Y.Q., ZHOU, F.C., GAO, F., BIAN, J.S. and SHAN, F., 2009. Comparative evaluation of quercetin, isoquercetin and rutin as inhibitors of $\alpha$-glucosidase. Journal of Agricultural and Food Chemistry, vol. 57, no. 24, pp. 11463-11468. http://dx.doi.org/10.1021/ jf903083h. PMid:19938837.

LUE, B.M., NIELSEN, N.S., JACOBSEN, C., HELLGREN, L., GUO, Z. and XU, X., 2010. Antioxidant properties of modified rutin esters by $\mathrm{DPPH}$, reducing power, iron chelation and human low density lipoprotein assays. Food Chemistry, vol. 123, no. 2, pp. 221-230. http://dx.doi.org/10.1016/j.foodchem.2010.04.009.

MARTYSIAK-ŻUROWSKA, D. and WENTA, W., 2012. A comparison of ABTS and DPPH methods for assessing the total antioxidant capacity of human milk. Acta Scientiarum Polonorum. Technologia Alimentaria, vol. 11, no. 1, pp. 83-89. PMid:22230978.

MASOOD, S., REHMAN, U.A., BASHIR, S., IMRAN, M., KHALIL, P., KHURSHEED, T., IFTHIKAR, F., JAFFAR, H.M., FAROOQ S., RIZWAN, B. and JAVED, N., 2020. Proximate and sensory analysis of wheat bread supplemented with onion powder and onion peel extract. Bioscience Research, vol. 17, no. 4, pp. 4071-4078.

MASOOD, S., REHMAN, U.A., BASHIR, S., SHAZLEY, M.E., IMRAN, M., KHALIL, P., IFTHIKAR, F., JAFFAR, H.M. and KHURSHEED, T., 2021. Investigation of the anti-hyperglycemic and antioxidant effects of wheat bread supplemented with onion peel extract and onion powder in diabetic rats. Journal of Diabetes and Metabolic Disorders, vol. 20, no. 1, pp. 485. http://dx.doi.org/10.1007/ s40200-021-00770-x. PMid:34222073.

MOTULSKY, H., 2020 [viewed 3 January 2021]. Graph Pad Prism [online]. Available from: https://www.graphpad.com/guides/ prism/latest/statistics/index.htm

MURAYYAN, A.I., MANOHAR, C.M., HAYWARD, G. and NEETHIRAJAN, S., 2017. Antiproliferative activity of Ontario grown onions against colorectal adenocarcinoma cells. Food Research International, vol. 96, pp. 12-18. http://dx.doi.org/10.1016/j. foodres.2017.03.017. PMid:28528091.

NENCINI, C., MENCHIARI, A., FRANCHI, G.G. and MICHELI, L., 2011. In vitro antioxidant activity of aged extracts of some Italian Allium species. Plant Foods for Human Nutrition, vol. 66, no. 1, pp. 11-16. http://dx.doi.org/10.1007/s11130-010-0204-2. PMid:21290188.

NILE, A., GANSUKH, E., PARK, G.S., KIM, D.H. and HARIRAM NILE, S., 2021. Novel insights on the multi-functional properties of flavonol glucosides from red onion (Allium cepa L) solid waste-In vitro and in silico approach. Food Chemistry, vol. 335, pp. 127650. http://dx.doi.org/10.1016/j.foodchem.2020.127650. PMid:32745842.

OBOH, G., ADEMILUYI, A.O., AGUNLOYE, O.M., ADEMOSUN, A.O. and OGUNSAKIN, B.G., 2019. Inhibitory effect of garlic, purple onion, and white onion on key enzymes linked with type 2 diabetes and hypertension. Journal of Dietary Supplements, vol. 16, no. 1, pp. 105-118. http://dx.doi.org/10.1080/19390211.201 8.1438553. PMid:29522359.

OKAMOTO, G., HAYASE, F. and KATO, H., 1992. Scavenging of active oxygen species by glycated proteins. Bioscience, Biotechnology, and Biochemistry, vol. 56, no. 6, pp. 928-931. http://dx.doi. org/10.1271/bbb.56.928. PMid:27280815.

OYAIZU, M., 1986. Studies on products of browning reaction: antioxidative activities of products of browning reaction prepared from glucosamine. Eiyogaku Zasshi, vol. 44, no. 6, pp. 307-315. http://dx.doi.org/10.5264/eiyogakuzashi.44.307.

PRAKASH, D., SINGH, B.N. and UPADHYAY, G., 2007. Antioxidant and free radical scavenging activities of phenols from onion (Allium cepa). Food Chemistry, vol. 102, no. 4, pp. 1389-1393. http://dx.doi.org/10.1016/j.foodchem.2006.06.063. 
RE, R., PELLEGRINI, N., PROTEGGENTE, A., PANNALA, A., YANG, M. and RICE-EVANS, C., 1999. Antioxidant activity applying an improved ABTS radical cation decolorization assay. Free Radical Biology \& Medicine, vol. 26, no. 9-10, pp. 1231-1237. http:// dx.doi.org/10.1016/S0891-5849(98)00315-3. PMid:10381194.

RICE-EVANS, C.A., MILLER, N.J. and PAGANGA, G., 1996. Structureantioxidant activity relationships of flavonoids and phenolic acids. Free Radical Biology \& Medicine, vol. 20, no. 7, pp. 933-956. http://dx.doi.org/10.1016/0891-5849(95)02227-9. PMid:8743980.

RODRÍGUEZ GALDÓN, B., TASCÓN RODRÍGUEZ, C., RODRÍGUEZ RODRÍGUEZ, E.M. and DÍAZ ROMERO, C., 2009. Fructans and major compounds in onion cultivars (Allium cepa). Journal of Food Composition and Analysis, vol. 22, no. 1, pp. 25-32. http:// dx.doi.org/10.1016/j.jfca.2008.07.007.

SAHA, B., IGLESIAS, M., DIMMING, I.W. and STREAT, M., 2000. Sorption of trace heavy metals by thiol containing chelating resins. Solvent Extraction and Ion Exchange, vol. 18, no. 1, pp. 133-167. http://dx.doi.org/10.1080/07366290008934676.

SCHIEBER, A., STINTZING, F.C. and CARLE, R., 2001. By-products of plant food processing as a source of functional compounds: recent developments. Trends in Food Science \& Technology, vol. 12, no. 11, pp. 401-413. http://dx.doi.org/10.1016/S09242244(02)00012-2.

SHETTY, K., CURTIS, O.F., LEVIN, R.E., WITKOWSKY, R. and ANG, W. 1995. Prevention of vitrification aßociated with in vitro shoot culture of oregano. (Origanum vulgare) by Pseudomonas spp. Journal of Plant Physiology, vol. 147, no. 3-4, pp. 447-451. http:// dx.doi.org/10.1016/S0176-1617(11)82181-4.

TADERA, K., MINAMI, Y., TAKAMATSU, K. and MATSUOKA, T., 2006. Inhibition of $\alpha$-glucosidase and $\alpha$-amylase by flavonoids. Journal of Nutritional Science and Vitaminology, vol. 52, no. 2, pp. 149153. http://dx.doi.org/10.3177/jnsv.52.149. PMid:16802696.

TAKAHASHI, M. and SHIBAMOTO, T., 2008. Chemical compositions and antioxidant/anti-inflammatory activities of steam distillate from freeze-dried onion (Allium cepa L.) sprout. Journal of Agricultural and Food Chemistry, vol. 56, no. 22, pp. 1046210467. http://dx.doi.org/10.1021/jf801220b. PMid:18942842.

VANACKER, H., GUICHARD, M., BOHRER, A.S. and ISSAKIDISBOURGUET, E., 2018. Redox regulation of monodehydroascorbate reductase by thioredoxin y in plastids revealed in the context of water stress. Antioxidants, vol. 7, no. 12, pp. 183. http://dx.doi. org/10.3390/antiox7120183. PMid:30563207.
VASQUEZ, M.I., LAMBRIANIDES, A., SCHNEIDER, M., KÜMMERER, K. and FATTA-KASSINOS, D., 2014. Environmental side effects of pharmaceutical cocktails: what we know and what we should know. Journal of Hazardous Materials, vol. 279, pp. 169-189. http://dx.doi.org/10.1016/j.jhazmat.2014.06.069. PMid:25061892.

VERMA, U., SHARMA, R., GUPTA, P., GUPTA, S. and KAPOOR, B., 2007. Allopathic vs. ayurvedic practices in tertiary care institutes of urban North India. Indian Journal of Pharmacology, vol. 39, no. 1, pp. 52-54. http://dx.doi.org/10.4103/0253-7613.30765.

VU, N.K., KIM, C.S., HA, M.T., NGO, Q.T., PARK, S.E., KWON, H., LEE, D., CHOI, J.S., KIM, J.A. and MIN, B.S., 2020. Antioxidant and antidiabetic activities of flavonoid derivatives from the outer skins of Allium cepa L. Journal of Agricultural and Food Chemistry, vol. 68, no. 33, pp. 8797-8811. http://dx.doi.org/10.1021/acs. jafc.0c02122. PMid:32603104.

WITKOWSKA-BANASZCZAK, E., RADZIKOWSKA, D. and RATAJCZAK, K., 2018. Chemical profile and antioxidant activity of Trollius europaeus under the influence of feeding aphids. Open Life Sciences, vol. 13, no. 1, pp. 312-318. http://dx.doi.org/10.1515/ biol-2018-0038. PMid:33817098.

WOISKY, R.G. and SALATINO, A., 1998. Analysis of propolis: some parameters and procedures for chemical quality control.Journal of Apicultural Research, vol. 37, no. 2, pp. 99-105. http://dx.doi. org/10.1080/00218839.1998.11100961.

WU, H. and XU, B., 2011. Inhibitory effects of onion against $\alpha$-glucosidase activity and its correlation with phenolic antioxidants. International Journal of Food Properties, vol. 17, no. 3, pp. 599-609. http://dx.doi.org/10.1080/10942912.2012.654562.

YE, C.L., DAI, D.H. and HU, W.L., 2013. Antimicrobial and antioxidant activities of the essential oil from onion (Allium cepa L.). Food Control, vol. 30, no. 1, pp. 48-53. http://dx.doi.org/10.1016/j. foodcont.2012.07.033.

YOO, K.S., LEE, E.J. and PATIL, B.S., 2013. Changes in quercetin glucoside concentrations of onion bulbs by scales, during storage, and in sprouting leaves exposed to UV. Postharvest Biology and Technology, vol. 83, pp. 65-71. http://dx.doi.org/10.1016/j. postharvbio.2013.03.016.

ZENG, Y., LI, Y., YANG, J., PU, X., DU, J., YANG, X., YANG, T. and YANG, S., 2017. Therapeutic role of functional components in alliums for preventive chronic disease in human being. Evidence-Based Complementary and Alternative Medicine, vol. 2017, pp. 9402849. http://dx.doi.org/10.1155/2017/7821095. PMid:28261311. 